\title{
El llegat dels germans Grimm en el segle XXI: del paper a la pantalla
}

\author{
Emili Samper Prunera \\ Universitat Rovira i Virgili \\ emili.samper@urv.cat
}

\begin{abstract}
RESUM
Les rondalles que els germans Grimm van recollir als Kinder- und Hausmärchen han traspassat la frontera del paper amb nombroses adaptacions literàries, cinematogràfiques o televisives. La pel-licula The brothers Grimm (2005), de Terry Gilliam, i la primera temporada de la sèrie Grimm (2OII-2OI2), de la cadena NBC, són dos mostres recents d'obres audiovisuals que han agafat les rondalles dels Grimm com a base per elaborar la seva ficció. En aquest article s'analitza el tractament de les rondalles que apareixen en totes dues obres (tenint en compte un precedent de I962, The wonderful world of the Brothers Grimm), així com el rol que adopten els mateixos germans Grimm, que passen de creadors a convertir-se ells mateixos en personatges de ficció. Es recorre, d'aquesta manera, el camí invers al que han realitzat els responsables d'aquestes adaptacions: de la pantalla (gran o petita) es torna al paper, mostrant quines són les rondalles dels Grimm que s'han adaptat i de quina manera s'ha dut a terme aquesta adaptació.
\end{abstract}

PARAules ClaU

Grimm, Kinder- und Hausmärchen, The brothers Grimm, Terry Gilliam, rondalla

SUMMARY

The tales that the Grimm brothers collected in their Kinder- und Hausmärchen have gone beyond the confines of paper with numerous literary, cinematographic and TV adaptations. The film The Brothers Grimm (2005), by Terry Gilliam, and the first season of the series Grimm (2OII-2OI2), produced by the NBC network, are two recent examples of audiovisual productions that have taken the Grimm brothers' tales as a base on which to create their fiction. This article analyses the treatment of the tales that appear in both works (taking into account the 1962 precedent, The Wonderful World of the Brothers Grimm), and the role adopted by the Grimm brothers themselves, who shifted from creators to fictional characters. Therefore, it retraces the route taken by those responsible for the adaptations: we move from the (small or large) screen back to paper, showing which of the Grimm brothers' tales have been adapted and how this adaptation has been brought about.

KEYWORDS

Grimm, Kinder- und Hausmärchen, The brothers Grimm, Terry Gilliam, tale

Estudis de Literatura Oral Popular, núm. I, 20I2, I33-I65

ISSN: 2OI4-7996 | http://revistes.publicacionsurv.cat/index.php/elop 


\section{Introducció: les adaptacions de les rondalles dels germans Grimm ${ }^{1}$}

Les rondalles que Jacob i Wilhelm Grimm van publicar als Kinder- und Hausmärchen (KHM), el primer volum dels quals compleix tot just ara el bicentenari (I8I2), són una de les grans obres reconegudes de la literatura universal que ha traspassat fronteres no solament lingüístiques (amb traduccions a més de I6o llengües), ${ }^{2}$ sinó també de format amb les adaptacions dels contes a altres àmbits, com el cinema, el còmic o la televisió. Des de la versió animada de Snow White and the seven dwarfs (Blancaneu $i$ els set nans) de Walt Disney de I937 fins a les més recents adaptacions en imatge real, com Snow White and the hunstman (Blancaneu i la llegenda del caçador) (2OI2), ${ }^{3}$ totes dues versions d'ATU 709 (KHM no 53 ), les rondalles recollides pels germans Grimm han estat versionades i portades a la pantalla gran, amb més o menys fortuna, des de fa molt temps. Aquest article no pretén revisionar totes les adaptacions que s'han dut a terme, ${ }^{4}$ sinó que se centrarà a veure de quina manera s'han adaptat les rondalles que apareixen en dos casos concrets: la pel-lícula The brothers Grimm (2005) i la sèrie de televisió Grimm (2OII-2OI2), així com quin paper hi han tingut els mateixos germans Grimm com a personatges, i no tant com a autors o recopiladors. Tot plegat ens podrà mostrar quin és el seu llegat i la seva pervivència en ple segle XXI, dos-cents anys més tard de l'aparició de les seves rondalles.

\footnotetext{
I. Aquest article forma part de la investigació del Grup de Recerca Identitats en la Literatura Catalana (GRILC), reconegut per la Generalitat de Catalunya (2009 SGR 644), i s'emmarca en una línia de recerca sobre literatura popular catalana que ha rebut finançament del Ministeri d'Economia i Competitivitat a través del projecte d'I+D FFI 2009-08202/FILO.

2. En l'àmbit lingüístic català destaquen amb llum pròpia les primeres traduccions de Carles Riba, publicades en els dos volums de Contes d'infants i de la llar (I9I9 i I92I) dins la Biblioteca Literària de l'Editorial Catalana, i en un nou volum, Rondalles de Grimm (I935) a l'Editorial Joventut (Samper 2OI2).

3. El 2or2 sembla l'any de la Blancaneu, ja que es poden veure a la gran pantalla fins a tres adaptacions. Per ordre d'estrena, Mirror, mirror (Blancaneu), de Tarsem Singh, amb Julia Roberts; l'esmentada Snow White and the hunstman (Blancaneu i la llegenda del caçador), de Rupert Sanders, amb Kristen Stewart, Chris Hemsworth i Charlize Theron, i l'espanyola Blancanieves, de Pablo Berger, amb Maribel Verdú. Les tres adopten diferents estètiques i presenten lectures diferents d'aquesta rondalla dels Grimm.

4. Altres autors ja s'han encarregat de fer-ho. En aquest sentit, l'estudi de Jack Zipes (2OII) n'és un bon exemple.
} 
El llegat dels germans Grimm en el segle XxI: del paper a la pantalla

\section{Un precedent: The wonderful world of the brothers Grimm} (1962)

Abans d'entrar en matèria i analitzar la primera pel-lícula, cal tenir en compte un precedent important, tant per la temàtica tractada, que l'enllaça amb la pel-lícula que s'analitzarà, com pel paper jugat en el seu moment, encara que no pertanyi al segle XxI. Es tracta de The wonderful world of the brothers Grimm (El meravellós món dels germans Grimm), una pel-lícula de 1962 nascuda de la mà del productor George Pal, dirigida per ell mateix amb codirecció de Henry Levin. La pel-lícula, que va rebre la nominació a quatre premis Oscar (I962) i es va endur el de disseny de vestuari (Mary Wills), 5 està basada en el llibre Die Brüder Grimm, un recull de cartes editades per Hermann Gerstner, del qual Pal en va comprar els drets per adaptar-lo a la pantalla l'any I956 (Lochner 20IO: I).

The wonderful world of the brothers Grimm pren com a base alguns aspectes de la vida real dels protagonistes i en fa la seva pròpia versió. La pel-lícula combina la part biogràfica d'en Jacob i en Wilhelm (dirigida per Henry Levin) amb la recreació d'algunes rondalles que s'insereixen dins

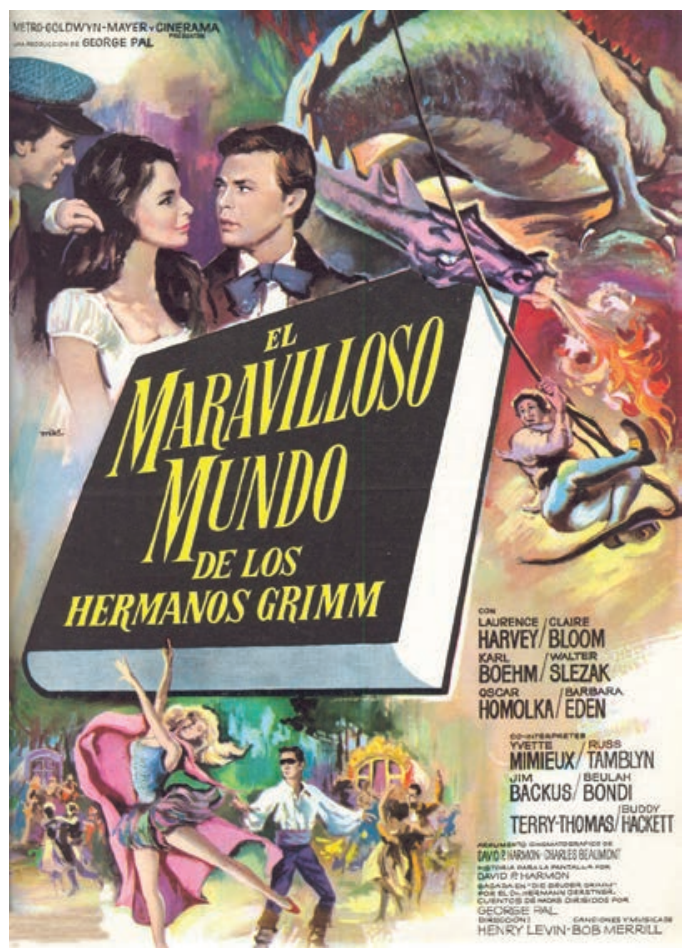

5. Les altres nominacions van ser en les categories de millor banda sonora (Leigh Harline), millor fotografia en color (Paul C. Vogel) i millor direcció artística en color (George W. Davis, Edward Carfagno, Dick Pefferle, Henry Grace). 
l'argument, amb una important presència musical (aquesta part dirigida per George Pal). La història se centra en Wilhelm (interpretat per Laurence Harvey) i Jacob (interpretat per Karlheinz Böhm) Grimm i barreja aspectes biogràfics i fantàstics. Els dos germans treballen en l'elaboració d'una història per al duc local (interpretat per Oscar Homolka), tot i que en Wilhelm està més interessat en la recopilació de rondalles de boca dels vilatans. Els germans no poden complir la data de lliurament del treball perquè en Wilhelm perd el manuscrit i es troben en greus problemes econòmics. Intentant salvar el manuscrit (que havia caigut a l'aigua), en Wilhelm emmalalteix de pneumònia i és a punt de morir. Es recupera després d'un somni on se li apareixen els personatges de les rondalles. Després d'aquesta experiència, en Wilhelm treballa de valent amb la gramàtica alemanya i els llibres de legislació i en Jacob s'involucra en l'interès del seu germà per les rondalles. La Reial Acadèmia de Berlín convida en Jacob a rebre el títol de membre honorari pels seus mèrits acadèmics (no per la labor de recol-lecció de rondalles), i prepara un discurs crític pel menyspreu sofert pel seu germà. Aleshores apareix una colla de nens que reclamen una rondalla. En Wilhelm pren la paraula dient: «Hi havia una vegada dos germans», i així finalitza la pel-lícula.

Inserides en la trama principal, trobem tres rondalles que David Harmon va adaptar lliurement a partir de les versions dels germans Grimm, escrivint el guió amb Charles Beaumont i William Roberts. Les rondalles dramatitzades són, en primer lloc, «The dancing princess» («La princesa balladora», ATU 306, KHM nº I33 «Die zertanzten Schuhe»), on Russ Tamblyn interpreta un llenyataire que, per tal de guanyar la mà d'una princesa (interpretada per Yvette Mimieux) i la meitat del regne, ha de descobrir el lloc on ella viatja cada nit i el motiu pel qual les seves sabates apareixen foradades cada matí. En segon lloc trobem «The cobbler and the elves» («El sabater i els follets», AaTh 503*, KHM no 39 «Die Wichtelmänner»), on Laurence Harvey interpreta un vell sabater que rep l'ajuda miraculosa d'uns follets màgics de fusta que l'ajuden a enllestir la seva feina. Finalment, a «The singing bone» («La flor de panical» en les versions catalanes, ATU 780, KHM nº 28 «Der singende Knochen»), Terry-Thomas interpreta un cavaller covard i Buddy Hackett el seu fidel servidor, en la recerca per matar un drac i guanyar fama i fortuna. Els cineastes havien previst inicialment incloure tres rondalles més, entre les quals trobaríem «Cinderella» («La Ventafocs», ATU 5IOA, KHM nº 2I «Aschenputtel») i «The fisherman and his wife» («El pescador i la seva dona», ATU 555, KHM n ${ }^{\circ}$ I9 «Von dem Fischer un syner Fru»). El motiu de voler incloure aquesta última no era altre que el de poder mostrar un nou procés del sistema Cinerama sota l'aigua que faria viatjar l'espectador en un recorregut a través dels boscos de coral de Key West (Lochner 20IO: 2). Precisament la utilització del format Cinerama és la gran novetat d'aquesta pel-lícula. De fet, va ser la primera pel-lícula dramàtica rodada d'aquesta manera, ja que, 
fins aleshores, aquesta tècnica només s'havia utilitzat per als documentals. Nascuda durant la dècada dels cinquanta del segle XX com a reacció davant la competència de la televisió, aquesta tècnica consistia a filmar amb tres càmeres sincronitzades com si fossin una de sola. La projecció es feia amb tres projectors de $35 \mathrm{~mm}$ treballant en sincronia, mostrant una imatge panoràmica, amb què s'incrementava així el detall i la grandària, sobre una enorme pantalla corbada. Tot i l'espectacularitat de la projecció i la claredat de la imatge, presentava el problema de les dues línies on s'unien els tres panells, que eren difícils d'amagar, la qual cosa era una distracció per a l'espectador. ${ }^{6}$

L'any I965, tres anys després de l'estrena de la pel-lícula, trobem l'adaptació en forma de novel-la il.lustrada, dins la col-lecció Historias, de l'Editorial Bruguera (no I93). L'adaptació és d'Eduardo Romero Peralta i alterna tres pàgines de text amb una pàgina de còmic, ${ }^{7}$ obra de Marcelo Guillamón Pardo. La sobrecoberta reprodueix una il.lustració de la pel-lícula. La reedició d'aquesta novel·la il·lustrada l'any I967, dins la collecció Serie Leyendas y Cuentos ( $n^{\circ} 9$ ), es va difondre amb èxit. Cal dir que aquesta mateixa col-lecció inclou precisament una antologia de rondalles dels germans Grimm que segueixen la mateixa estructura, combinant pàgines de text i còmic. Es tracta del número 6 de la col-lecció, publicada per primer cop l'any I958, i que porta per títol Cuentos de Grimm. La traducció espanyola de les 2I rondalles d'aquesta antologia és de Montserrat Canal Rifa, la sobrecoberta d'Antonio Bosch Penalva i les il.lustracions interiors de Lluís Casamitjana Colominas. ${ }^{8}$ Com a curiositat, a la solapa d'aquesta antologia hi apareix com a únic autor de les rondalles Jacob Grimm ( Jacobo Luis Carlos Grimm») i en Wilhelm apareix esmentat només quan es parla de la seva relació amb Kassel i Marburg.

6. El format Cinerama i, sobretot, els danys dels negatius originals de la pel-lícula n'han impedit, fins ara, l'adaptació als formats domèstics actuals, com el DVD i el Blu-ray, per la qual cosa es fa difícil actualment aconseguir una còpia de la pel-lícula. A la televisió s'ha emès unes quantes vegades, entre les quals Televisió de Catalunya la va emetre el 24 de desembre de 1996 , doblada al català.

7. De les 258 pàgines del llibre, 64 són de còmic.

8. Les 2I rondalles són: «Los seis cisnes» (KHM no 49$)$, «El rey rana» (KHM no I), «Juanito y Margarita» (KHM no ${ }^{\circ}$ 5), «El doctor Sabelotodo» (KHM nº 98), «Blancanieves» (KHM nº 53), «Los ducados caídos del cielo» (KHM no I53), «El judío en el espín» (KHM no IIO), «Los tres pelos de oro del duendecillo» (KHM no 29 ), «Blancanieve y Rojaflor» (KHM n I6I), «La casa del bosque» (KHM no I69), «El agua de la vida» (KHM no 97), «La lámpara azul» (KHM no II6), «La mesa, el asno y el bastón maravilloso» (KHM no 36 ), «El rey 'Pico de Tordo'» (KHM $\mathrm{n}^{\circ}{ }^{52}$ ), «La ondina del estanque» (KHM n $\left.{ }^{\circ} \mathrm{I} 8 \mathrm{I}\right)$, «'Bestia peluda’» (KHM n 65$)$, «Elsa, la lista» $\left(\mathrm{KHM} \mathrm{n}^{\circ} 34\right)$, «La pastora de ocas en la fuente» (KHM no I79), «Monte Semsi» (KHM nº I42), «La gallinita y el pollito» (KHM no 8o) i «'Piel de Oso'» (KHM nº IOI). 


\section{El món de Terry Gilliam: The brothers Grimm (2005)}

L'any 2005, el director Terry Gilliam s'endinsa en l'imaginari dels germans Grimm amb l'estrena de la pel-lícula The brothers Grimm, ${ }^{9}$ una adaptació de gènere fantàstic de la vida d'en Jacob i en Wilhelm passada pel particular sedàs d'aquest membre dels Monty Python. El film, dirigit per Gilliam, està escrit per Ehren Kruger, però el mateix Gilliam i Tony Grisoni reescriuen bona part del guió original, hi introdueixen canvis substancials i lliguen més l'argument a les rondalles dels germans Grimm. Des de bon començament, la pel-lícula es veu envoltada de problemes de tot tipus. A la reescriptura del guió (un fet que s'explica per la intervenció del director, com aclareix McCabe 2006: I6 i 23), s'hi sumen problemes de finançament que encareixen la producció (amb l'abandonament de la Metro Goldwyn Mayer i el pas endavant del mateix Gilliam com a productor, encara que refusi aparèixer als crèdits com a tal, McCabe 2006: 43), ${ }^{\circ} \mathrm{de}$

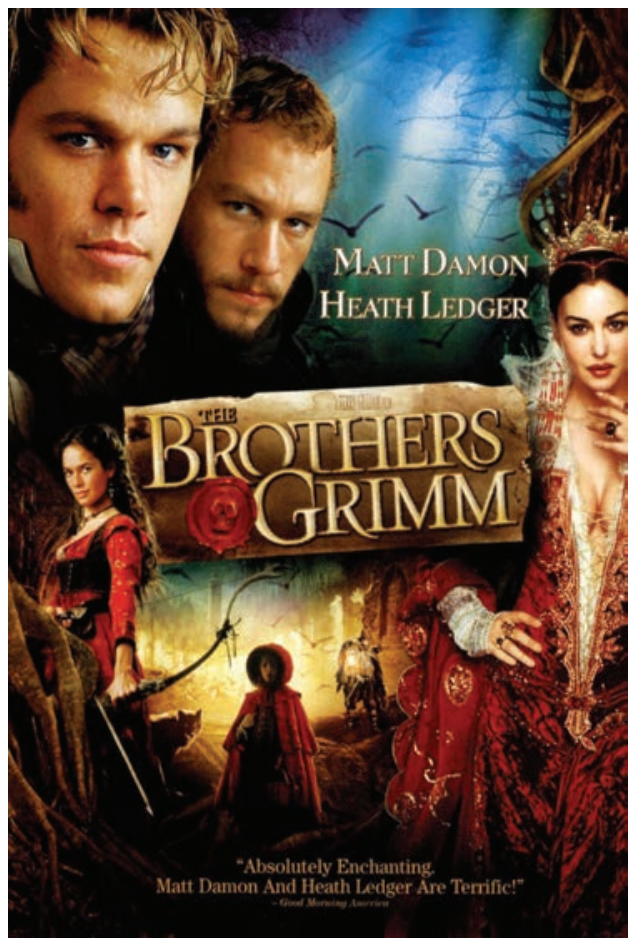

\footnotetext{
9. Traduïda com El secreto de los hermanos Grimm a Espanya, també hi ha versió catalana ( $E l$ secret dels germans Grimm), emesa per primer cop a Televisió de Catalunya el 28 de desembre de 2007.

Io. Inicialment, el projecte estava en mans de la productora Metro Goldwyn Mayer, que va buscar l'ajuda de Dimension, la divisió de terror-fantàstic de Miramax, per compartir els costos. L'abandonament de la Metro (abans de ser venuda a Sony) va deixar el projecte en mans únicament de Miramax (Spines 2005: 95).
} 
càsting (que endarrereixen l'inici de la gravació), canvis també en la fotografia (Newton Thomas Sigel substitueix Nicola Pecorini per l'excessiva foscor de Pecorini), entre d'altres (Spines 2005: 95). ${ }^{\text {II }}$ De fet, fins i tot un cop acabat el rodatge, no es tenia clar si s'aconseguiria enllestir la pellícula. McCabe recull el testimoni dels mateixos treballadors el dia que es lliuraven les cartes d'acomiadament que donaven per finalitzada la seva feina (el I4 de novembre de 2003), amb la circulació oral d'un poema que hauria pogut pronunciar la mateixa bruixa de la rondalla de Blancaneu davant del mirall màgic:

Miramax, Miramax on the wall

What is the most incomplete film of them all?

The Brothers Grimm (Mc Cabe 2006: 270).

No sorprèn doncs, que una de les conseqüències d'aquest rodatge tan problemàtic sigui l'endarreriment de l'estrena de la pel-lícula. Prevista per al novembre de 2004, finalment s'estrena el 26 d'agost de $2005 .{ }^{\text {.2 }}$ Això fa que pel-lícules que els protagonistes havien rodat després s'estrenin abans. És el cas de l'actor Matt Damon amb The Bourne supremacy (estrenada al juliol de 2004) i Ocean's Twelve (estrenada al febrer de 2005) i del mateix Gilliam, que el 2005 estrenarà també Tideland, tan sols un mes després de The brothers Grimm. Aquest endarreriment, però, té una part positiva i és que afavoreix el muntatge final del film, segons el seu director:

Siempre he dicho si no sería bonito acabar una película y alejarte y regresar a ella al cabo de seis meses con una mirada fresca. Es lo que ha sucedido aquí, y los resultados han mejorado. Tuvimos que dejar fuera la secuencia más cara, en la que los hermanos rescatan a Angelika de un árbol-monstruo. Fue algo difícil, pero la acción funciona mejor sin ella. Y tardé seis meses en darme cuenta (Spines 2005: 95).

Sobre la relació de Gilliam amb les rondalles dels Grimm, ell mateix reconeix que «las historias de los Grimm me han convertido en lo que soy» (Spines 2005: 93). Pel que fa a l'ambientació més aviat fosca que envolta la pel-lícula (tot i els canvis introduïts en la fotografia esmentats anteriorment), Gilliam fuig de les versions més ensucrades que ens han arribat per altres vies i vol recuperar l'essència de les rondalles i també el seu costat més màgic, encara que això l'allunyi de la comercialitat:

Cuando me pongo a trabajar me olvido de lo que es o no es comercial. Queríamos recuperar la esencia de los cuentos de hadas, crear un mundo que no solo resultara creíble y aterrador, sino también

II. Per als detalls del rodatge i tots els problemes interns que aquí només he apuntat, resulta molt interessant el llibre de McCabe (2006), que recull, en forma de diari, tot el procés, i compta amb el testimoni dels principals protagonistes.

I2. A Espanya la pel-lícula s'estrena el 9 de setembre de 2005 .

Estudis de Literatura Oral Popular, núm. I, 2012 
mágico. No queríamos convertir esto en un nuevo Van Helsing (Stephen Sommers, 2004), que no tuvo nada que ver con el encantamiento o la magia. Para mí, la mejor fantasía surge cuando aquello que conocemos no se comporta como esperábamos (Spines 2005: 94).

Encara més, el director aspira a recuperar aquesta barreja de por i plaer que produeix la lectura de les rondalles originals:

Los cuentos de los hermanos Grimm son oscuros, era importante para mí no hacer una insípida versión moderna de lo que los cuentos de hadas serían hoy. Los cuentos de hadas de los hermanos Grimm me daban mucho miedo cuando era un niño y también me gustaban muchísimo (Alarcón 20IO: I3I).

Per tal d'aconseguir-ho, la pel-lícula ens presenta una sèrie d'elements procedents de rondalles dels Grimm dins la història, adaptades pel seu director, que actua també com a guionista. A diferència de The wonderful world of the brothers Grimm (I962), aquí les rondalles (o, més ben dit, les referències a les rondalles) es troben totalment inserides dins l'argument i no es presenten com a episodis aïllats i diferenciats de la trama principal.

\subsection{Les rondalles dins la pel-lícula}

La pel-lícula ens presenta en Jake (Jacob Grimm, interpretat per Heath Ledger) i en Will (Wilhelm Grimm, interpretat per Matt Damon) en el context d'una Alemanya ocupada per les tropes napoleòniques que segueixen la idea de suprimir qualsevol rastre de cultura local que recordi l'antic règim i que amenaça, d'aquesta manera, el món que representen les rondalles. Aquesta autoritat és tractada de manera humorística per Gilliam:

[Gilliam] muestra como Alemania sufrió la humillación de la mano de las tropas francesas. En un contexto tan duro, Gilliam ha tratado de divertirse a expensas de los franceses, a los que muestra como verdaderos peleles amanerados y opulentos, un perfil muy cercano al tópico francés, [...] y que se ve simbolizado en el personaje de Jonathan Pryce, el general Vavarín Delatombe y sus caricaturizadas tropas (Alarcón 20IO: I33-I34).

En aquest context, els dos germans intenten guanyar-se la vida estafant els pobres i ignorants vilatans. Els expliquen històries de suposats monstres, esperits i fantasmes que viuen en determinats llocs d'aquestes encontrades per oferir després els seus serveis com a exorcistes, a canvi sempre de diners. Les autoritats franceses els descobreixen i els obliguen a actuar en un cas real de desaparició de nenes que té lloc prop d'un bosc encantat. Amb l'ajuda de l'Angelika (interpretada per Lena Headey), les germanes i el pare de la qual també han desaparegut, descobreixen que la 
responsable és una malvada bruixa (la reina del mirall, interpretada per Monica Bellucci) que utilitza les nenes per conservar la seva joventut.

Aquest és l'argument principal de la pel-lícula, que es desenvolupa durant les quinze escenes que la conformen i que són les següents: I. Inici; 2 . Meanwhile; 3. Capturats; 4. Un poble de Marbaden; 5. La llegenda; 6. Engolida; 7. Animals abduïts; 8. Celebritats; 9. Intent frustrat; IO. La cosa; II. La salvació; I2. El bosc cremat; I3. La lluita; I4. Destrucció; I5. Desenllaç.

A continuació, faré el camí invers realitzat pels guionistes (que utilitzen les rondalles dels germans Grimm com a base per a la pel-lícula) per extreure aquells elements procedents de les rondalles que hi apareixen i veure de quina manera ho fan. En cada cas, s'assenyala l'escena de la pellícula (títol i número), el títol de la rondalla i el tipus rondallístic (seguint en tots dos casos el catàleg internacional ATU, Uther 2004), el número i el títol de la versió de la rondalla recollida pels germans Grimm als Kinder- und Hausmärchen (KHM), seguida de la traducció catalana; ${ }^{13}$ després hi figuren la descripció i els comentaris pertinents.

(1) «Inici» (escena I), «Jack and the beanstalk» («Jack i la favera»), ATU $328 \mathrm{~A}$.

L'escena inicial de la pel-lícula, situada a l'any I796 i que arrenca amb la inevitable fórmula inicial «Once upon a time» de les rondalles, ens presenta els seus protagonistes (en Jake i en Will) de petits, amb la seva mare i la seva germana malalta, en una situació d'extrema gravetat. En Jake ha sortit per vendre la vaca (l'únic que els queda) i així poder pagar el metge, però quan torna ha canviat la vaca a un desconegut per unes faves màgiques que suposadament han de curar la seva germana, fet que provoca la ira d'en Will. Aquesta primera escena, amb la presència d'aquestes «faves màgiques», ens remet a la rondalla de «Jack i la favera» (ATU 328A) i al motiu F54.2. «Plant grows to sky» (Thompson I955-I958). ${ }^{14}$ Uther (2004: 2I8) anota que la favera com a mitjà per pujar al cel (característica d'aquest tipus) té l'origen en un relat anglès del segle Xviı, la primera versió del qual s'ha documentat l'any r8o7. Tot i que se'n troba una versió alemanya, no hi ha cap relació entre aquesta rondalla i els germans Grimm. Així, la pel-lícula comença amb una referència rondallística (només s'apunta la presència de les «faves màgiques») que no apareix al corpus recollit pels germans Grimm. Aquest element reapareixerà més endavant, lligat a la caracterització dels dos protagonistes, com ja veurem, motiu pel qual no es tracta d'un element menor.

I3. Utilitzaré, sempre que sigui possible, la traducció catalana de Carles Riba, que es pot trobar a Samper (2012).

I4. Estalvio, des d'ara, fer explícita la referència a Thompson (I955-I958) quan parli dels motius, per alleugerir el text. 
(2) «Meanwhile» (escena 2), «Little Red Riding Hood», ATU 333, KHM nº 26 «Rotkäppchen» («Caputxeta Vermella»).

Després del pròleg, la pel-lícula fa un salt en el temps per situar-nos en el present, quinze anys més tard de l'escena inicial i amb els protagonistes ja adults. En aquesta segona escena, trobem una nena vestida amb una caputxa vermella que desapareix al bosc de Marbaden, en una evident recreació de l'inici de la coneguda rondalla de la «Caputxeta Vermella» (ATU 333), que retrobarem més endavant.

(3) «Capturats» (escena 3), «Hansel and Gretel», ATU 327A, KHM nº I5 «Hänsel und Gretel» («Ton i Guida»).

Si una part de l'argument de la pel-lícula gira al voltant de la misteriosa desaparició de les nenes d'un poble, no és estrany que una de les rondalles que aparegui en el film sigui la de «Hänsel und Gretel» (ATU 327A), protagonitzada per dos germans que desapareixen al bosc. Aquesta rondalla, coneguda també com la de «La caseta de sucre i xocolata», es recrea a l'escena 3 protagonitzada precisament pel Hans (interpretat per Martin Svetlik) i la Greta (interpretada per Denisa Vokurkova), dos germans d'aquest poble maleït que entren al bosc a buscar les nenes desaparegudes. És en aquest escenari on la Greta diu: «I al bell mig del bosc, hi havia la caseta de xocolata de la vella bruixa», fent encara més evident la relació entre aquesta escena i la rondalla recollida pels Grimm. En aquest cas, però, únicament desapareix Greta (és una nena, com la resta de víctimes de les desaparicions anteriors), que, perseguint el seu mocador, entra dins d'una cova.

(4) «La llegenda» (escena 5), «The maiden in the tower», ATU 3IO, KHM no I2 «Rapunzel» («Repunxó»).

Una altra rondalla que apareixerà repetida al llarg de la pel-lícula és «Rapunzel» (ATU 3IO). A l'escena cinc, un flashback ens explica la història de la reina (del mirall), que fa construir una torre i s'hi tanca per salvar-se dels horrors de la pesta que ha arrasat el poble. La vinculació amb la rondalla, també recollida pels Grimm, és l'aparició de la llarga cabellera de la reina a la finestra, com la protagonista de la història, que és el motiu F848.I «Girl's long hair as ladder into tower». En aquesta escena, però, el cabell de la reina no té (encara) aquesta funció d'ajudar a pujar la torre, que retrobarem més endavant. 
(5) «Engolida» (escena 6), «The frog king or Iron Henry», ATU 440, ${ }^{15}$ KHM n ${ }^{\circ} \mathrm{I}$ «Der Froschkönig oder der eiserne Heinrich» («El rei granota o en Janferrís»).

En aquesta escena, l'Angelika li pregunta a l'àvia gripau pel camí de tornada a casa des del bosc encantat i li promet, a canvi, un petó. Aquesta transformació que trobem a ATU 440 (amb una versió recollida pels germans Grimm) i que aquí només s'insinua (l'àvia gripau no recupera la seva suposada forma humana anterior), és el motiu D735.I «Beauty and the beast. Disenchantment of animal by being kissed by woman (man)».

(6) «Engolida» (escena 6), «Snow White», ATU 709, KHM no 53 «Sneewittchen» («Blancaneu»).

En aquesta sisena escena trobem dos detalls procedents de dues rondalles diferents. La primera està extreta de «Blancaneu» (ATU 709). La vella del poble dóna a Mercurio Cavaldi (interpretat per Peter Stormare) una poma, que ell no es menja. Podem endevinar en aquest detall l'ús d'una suposada poma enverinada que trobem als motius Di364.I6 «Apple causes magic sleep» i SIII.4 «Murder with poisoned apple» que apareixen en aquest tipus. L'acció de l'enverinament no es duu a terme, amb la qual cosa podem veure'n la inclusió dins aquesta escena com una juguesca més dins la trama.

(7) «Engolida» (escena 6), «Little Red Riding Hood», ATU 333, KHM nº 26 «Rotkäppchen» («Caputxeta Vermella»).

En la mateixa escena 6 trobem la segona rondalla, que, en aquest cas, ja havia aparegut anteriorment (a 2). Es tracta d'una escena molt coneguda de la «Caputxeta Vermella» (ATU 333) i protagonitzada per l'Elsie (interpretada per Veronika Loulova), una nena del poble. En aquest cas, no és el llop qui se la menja (com trobem a la Caputxeta), sinó el cavall d'en Jacob prèviament embruixat en la seva visita al bosc encantat. En una escena resolta de manera intel-ligent des d'un punt de vista tècnic (atesos els recursos disponibles), el cavall es menja la nena, just després que ella pronunciï la frase tan coneguda i característica d'aquesta rondalla, com és «Quins ulls més grossos que tens, i quines orelles més grosses i quina boca més reboniqueta», que és el motiu ZI8.I «What makes your ears so big? - To hear the better, my child, etc.». El cavall, amb la nena a la panxa, desapareix a l'escena següent.

(8) «La cosa» (escena Io), «The fleeing pancake» («L'home de gingebre»), ATU 2025.

L'escena io ens porta la recreació d'una rondalla que no apareix al recull dels germans Grimm (com ja passava a l'escena inicial, I). Es tracta de

I5. Relacionat amb aquest tipus, trobem ATU $402 \mathrm{~A}^{*}$ («The princess transformed into a toad»), molt més sintètic i que se centra en la transformació, que és, de fet, el motiu utilitzat en aquesta escena de la pel-lícula. Però l'he adscrit a ATU 440 per la seva vinculació amb la versió dels Grimm (KHM no I), que pertany a aquest tipus. 
«The fleeing pancake» (ATU 2025), també coneguda com «The gingerbread man». La Sasha (interpretada per Laura Greenwood), una de les nenes del poble disfressada de nen per evitar ser raptada, va al pou a buscar aigua. Del pou, en treu un corb que li fa desaparèixer el rostre. De la galleda en surt una forma de fang, amb els seus ulls, que se l'acaba empassant (tot i els intents frustrats del seu pare i de l'Angelika per evitar-ho) i la transforma en l'home de gingebre. Aleshores, menjant-se un dit, la Sasha diu, tot cantant alegrement: «Mmm... Que bo que sóc. No m'atrapareu! Sóc l'home de gingebre!», i fuig a través del pou. Díaz i García observen com aquesta presència d'éssers híbrids i deformes, distorsions de la vida humana, és una constant en l'obra de Gilliam. I en aquest cas concret:

De modo parecido, Los hermanos Grimm recupera los monstruos provenientes del folklore que plagan los cuentos de éstos, desde la reina inmortal a los árboles humanoides. En la película, vemos cómo parte de la identidad se concentra en el rostro, y el horror que provoca la pérdida de rasgos faciales, que simbolizan la percepción: Sacha, una niña disfrazada de niño para evitar ser raptada por la reina, cae al pozo. El limo del pozo absorbe sus ojos, nariz y boca. De ese limo informe se conforma un pequeño homúnculo que le ha robado los rasgos: el Gingerbread Man (Díaz/García 20Io: 25).

(9) «La salvació» (escena II), «The frog king or Iron Henry», ATU 440, ${ }^{16}$ KHM n ${ }^{\circ}$ I «Der Froschkönig oder der eiserne Heinrich» («El rei granota o en Janferrís»).

L'escena onze inclou fins a cinc referències a rondalles. En la primera, ens retrobem amb la mateixa que havia aparegut a 5, amb el motiu D735.I. En aquest cas, és en Will qui besa el gripau per saber com pot sortir del bosc i el resultat és encara molt més còmic, si es compara amb l'anterior.

(10) «La salvació» (escena II), «Sleeping beauty», ATU 4IO, KHM nº 50 «Dornröschen» («Englantina»).

La segona referència prové de la rondalla de «La bella dorment» (ATU 4IO), també recollida pels Grimm, i la recreació consisteix a mostrar-nos la Sasha (la nena que s'havia transformat en l'home de gingebre a 8) adormida dins la tomba, amb la resta de nenes segrestades per la reina del mirall. Es tracta del motiu Di960.3 «Sleeping beauty».

(11) «La salvació» (escena II), «Cinderella», ATU 5IOA, KHM no 2 I «Aschenputtel» («La Cendrosa»).

La mateixa Sasha ens acosta la referència a una nova rondalla. En aquest cas, a través d'un element concret, com són les sabates de cristall que duu posades dins la tomba. Es tracta del motiu F823.2 «Glass shoes», que relaciona aquesta escena amb la «Ventafocs» $\mathrm{O}$ «Cendrosa» (ATU 5IOA).

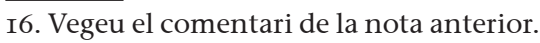


(12) «La salvació» (escena II), «Snow White», ATU 709, KHM nº 53 «Sneewittchen» («Blancaneu»).

Un altre element màgic entra en escena quan la reina del mirall es desperta, davant la presència d'en Jake, i fa ús dels seus poders per temptar-lo. Relaciono aquesta escena amb la rondalla de la «Blancaneu» (que ja havia aparegut a 6) per la presència del motiu Diı63 «Magic mirror».

(13) «La salvació» (escena II), «The maiden in the tower», ATU 3IO, KHM no I2 «Rapunzel» («Repunxó»).

Retrobem una altra referència que ja havíem vist només insinuada a 4 . Si en aquella ocasió se'ns mostrava en pantalla la reina del mirall amb una gran cabellera que penjava de la finestra de la torre, ara és quan aquests cabells tenen el paper actiu que els correspon en el motiu F848.I, quan en Jake es llença de la torre utilitzant els cabells de la reina com a corda. En aquest cas, la utilització dels cabells (d'un color i una textura que evidencien l'edat real de la reina i que es contraposa amb l'aspecte que té en la versió més coneguda) funciona com una ajuda per al protagonista (en Jake, en aquest cas), però no per pujar a salvar la princesa (la reina del mirall en aquest cas), sinó per fugir-ne.

(14) «Destrucció» (escena I4), «Sleeping Beauty», ATU 4IO, KHM no 50 «Dornröschen» («Englantina»).

La darrera rondalla que trobem reprèn la seqüència vista a Io i és la conseqüència lògica dels fets apuntats: només es pot desfer l'encanteri de la bella dorment amb un petó. Això sí, com remarca un dels personatges (Cavaldi), no pot ser un petó qualsevol: «Jo el conec aquest conte. De quan era molt petit. Encara hi som a temps, Jacob. Mireu! Va, veniu, de pressa. Encara podem desfer el conjur amb un petó. Un bes d'amor pur. Sobretot que al vostre cor hi hagi amor. O aquest bes serà el bes de la mort». En Jake besa l'Angelika, que es desperta, al mateix temps que es desperten les altres nenes, en un efecte dominó, sense que hi hagi contacte físic. Després, en Jake vol besar el seu germà Will per despertar-lo, però ell li diu a cau d'orella «Tu no». És aleshores quan l'Angelika besa en Will i ell li diu: «Ho havia de provar abans que s'acabés el conte». Apareixen aquí els motius D735 «Disenchantment by kiss» i Di978.5 «Waking from magic sleep by kiss» que desemboquen amb el final feliç que tanca la pel·lícula.

Hem vist fins a catorze seqüències on es reprodueixen diferents rondalles dins de la pel-lícula. Com s'ha vist en detall, de fet, el que trobem inserits dins la trama argumental de la pel-lícula són més aviat motius i no tipus rondallístics complets. La història principal de la reina del mirall s'estructura, bàsicament, sobre dos tipus, que són «Snow White» (ATU 709) $\mathrm{i}$ «Sleeping beauty» (ATU 4IO), que apareixen sintetitzats en diferents escenes. La resta de rondalles tenen una incidència menor dins la trama principal, però l'enriqueixen i la suma de totes elles configura l'essència de la pel-lícula unint la vida dels dos protagonistes amb els principals mo- 
tius que apareixen en algunes de les seves rondalles. En aquest sentit, cal dir que totes les rondalles escollides formen part del corpus recollit pels Grimm, excepte dues que ja he assenyalat: (I) «Jack and the beanstalk» (ATU 328A) i (8) «The fleeing pancake» (ATU 2025). En el primer cas, no és una referència banal perquè està relacionada $\mathrm{amb}$ la personalitat dels protagonistes i amb la trama inicial i final del film, com veurem a continuació. En el segon, es tracta d'una opció triada deliberadament per part del director, seguint la seva línia estètica.

\subsection{Els germans com a personatges}

La caracterització dels dos protagonistes (Jake i Will) és clara des de l'inici de la pel-lícula i la seva contraposició de caràcters es fa evident a la primera escena, amb la referència a les faves màgiques, on en Jake adopta el paper d'innocent (més que beneit) que creu en les solucions màgiques i en Will, per la seva banda, té els peus a terra, conscient de la difícil situació que viuen. Quan els personatges es fan adults, aquesta contraposició continua vigent. Així, mentre en Will és qui s'encarrega de la part més material en la seva tasca d'exorcistes i és qui tanca els tractes econòmics, en Jake embolcalla les històries que expliquen als pobles amb els elements que recull pels llocs on passen i que anota al seu llibre de rondalles, en una clara referència als Kinder- und Hausmärchen. Aquest llibre, que en Jake no abandona mai, té una breu aparició rellevant a la part final de la pel-lícula (escena I2), quan el general Vavarin Delatombe (interpretat per Jonathan Pryce) fa una pira per cremar els dos protagonistes amb tot el bosc i diu: «Adéu, Grimms. I adéu també als vostres contes. Ningú no els recordarà [llençant el llibre]», en una clara al·lusió a, precisament, el que no ha passat amb les rondalles dels germans Grimm, conegudes i recordades arreu del món.

En aquest mateix context, durant la pel-lícula podem sentir frases com «Jo abans era un erudit» (Jake, escena I), amb clara referència a la persona real en què es basa el personatge, i, sobretot, «Pensa que per a nosaltres és molt emocionant tot això. Les nostres faules estan inspirades en llocs com aquest. És estrany, però, miris on miris, pots sentir l'antic poder del bosc» (Jake a Angelika, escena 5). En Jake ha passat de recollir les rondalles i d'utilitzar-les segons la seva conveniència (seguint les ordres del seu germà) a viure-les en primera persona.

La contraposició dels caràcters dels dos germans apareix durant tota la pel-lícula, però si hi ha un moment on es manifesta més clarament és a l'escena 9, quan en Jake descobreix el que està passant realment al poble i qui és la responsable de la desaparició de les nenes. En el diàleg entre els dos germans es veu clarament aquests dos punts de vista: 
El llegat dels germans Grimm en el segle XxI: del paper a la pantalla

JAKE: Recordo el final del conte.

WiLL: Em pots dir de què parles?

JAKE: D'una faula que ha passat de pares a fills.

WILL: Prou, Jake.

JAKE: La torre, la reina, el que ens va dir... Mira, abans de la pesta...

WILL: Jacob!

JAKE: ... la reina torturava i matava els avantpassats d'aquesta gent per quedar-se amb els encanteris. Un servia per aconseguir la vida eterna.

WILL: Dóna'm aquest coi de llibre!

JAKE: La reina és a la torre. Encara hi és.

WiLl: Mira, hi ha una cosa que vull que entenguis: el conte no hi té res a veure, amb això. Tot plegat és per ella [Angelika]. La vols rescatar.

JAKE: Naturalment, perquè ella forma part del conte [escena 9].

Es fa patent també aquí el triangle amorós format pels dos germans i per l'Angelika, resolt de manera parcial al final de la pel-lícula, com hem vist més amunt. El diàleg no acaba aquí, sinó que les diferències entre en Jake i en Will s'accentuen quan el primer s'adona que han passat de ser espectadors (i recol-lectors, si se'm permet) de les rondalles a ser-ne els protagonistes:

ANGELIKA: Només és un conte per espantar els nens.

JAKE: Home, no ben bé, tampoc. Sé del cert que tu hi creus.

Will: No li facis cas. Li agradaria que la seva vida fos part d'un llibre i ara creu que està enamorat.

JAKE: Tu calla, entesos?!

Will: Fes [a Angelika] el que volia el teu pare i ves-te'n corrents del poble.

ANGELIKA: No, Will. Vull trobar les meves germanes.

JAKE: Que et penses que li importen? A ell no li importa res tret d'ell mateix.

Will: Això no és un conte de fades, no tornaran mai més!

JAKE: Aquest món no és el teu! Angelika, tu ho saps, oi? El conte ens passa a nosaltres. L'estem vivint, és viu, és real, respira! Li podem trobar un final feliç.

ANGELIKA: Jake...

JAKE: Trobarem les teves germanes, de veritat. I les tornarem al poble.

WiLL: Les seves germanes? Les faràs tornar? I com les faràs tornar? Amb faves màgiques?

JAKE: Per què ho dius això?

Will: Les faves màgiques no funcionen. No fan que les persones tornin a viure. No ho van fer llavors i no ho faran ara! [escena 9].

La referència a les faves màgiques de «Jack and the beanstalk» (ATU 328A) apareix de nou i enllaça amb l'escena inicial de la pel-lícula. Aquest ele- 
ment és el que agafa el director per mostrar-nos la diferència de caràcter entre els dos germans. I no deixa de ser curiós que precisament l'element triat no tingui cap relació amb el recull original dels Grimm.

La conversa reproduïda entre en Jake i en Will posa de manifest la diferent percepció de realitat i ficció que tenen tots dos:

Will, por su parte, se muestra reacio a admitir que lo que allí está sucediendo es fantástico; él ha sido siempre la parte cerebral y más realista en la pareja de hermanos. Además le cuesta creer que los cuentos de hadas de los que habían estado viviendo durante los últimos años, con sus pequeñas estafas, puedan ser reales. Jacob, sin embargo, es la cara más fantasiosa de los dos y se desenvuelve con mayor soltura en el mundo de los cuentos de hadas. Es capaz de interpretar los símbolos y códigos propios del mundo de la fantasía [...]. Will siempre ofrece una cara más realista y decidida; por su parte, Jacob ofrece una postura más recatada y fantasiosa; de manera que se genera una fidedigna relación entre hermanos en la que sus estados, el uno con respecto al otro, fluctúan en todo momento. En este devenir, Jacob es quien, definitivamente, ayuda a Will a entender que hay cosas que no necesitan una explicación, pues únicamente suceden en el mundo de la Magia (Alarcón 20I0: I38).

En Jake insisteix en la seva visió del món i la descoberta del seu paper en la història: «M'he passat tota la vida estudiant rondalles! I ara en trobo una que és real! No són fades, és real. Que no ho entens? Ho he de fer» (escena 9). Finalment, la successió d'esdeveniments porta en Will a abandonar la seva postura i a acostar-se a la del seu germà, fins al punt que, a l'escena I4, en l'enfrontament final amb la reina del mirall, li diu: «Tu la pots aturar. Aquest món és el teu, depèn només de tu. Acaba el conte! [...] Tu ho pots aturar, tu saps el conte! Només tu, només tu» (escena I4). Aquesta batalla entre racionalitat i fantasia es resol en aquest enfrontament final, on:

The final confrontation is not between Mirror Queen and Angelica, but instead involves Jacob and the Queen, shifting the emphasis to the conflict between rationalism and folk belief. Symbolically, before he can defeat the Queen, Jacob (folk belief) must stab Wilhelm (rationalism), who tells him, «This is your world, Jake... You can stop it. You know the story.» Angelica instead, despite initial potential, becomes the twelfth victim of the Mirror Queen, supplying the twelfth drop of blood needed to complete her spell, and must be woken from her enchanted sleep by a kiss from Jacob. However, she in turn wakes Wilhelm with a kiss, and the competition between the two brothers relating to Angelica is never resolved (Cahill 20I0: 64).

El director no es manté al marge d'aquesta dicotomia entre realitat/fantasia i pren partit per un dels protagonistes, fet que respon a la seva personalitat, reflectida també en la seva trajectòria cinematogràfica: 
El secreto de los hermanos Grimm vuelve a ser una nueva manifestación del rechazo de su director a la tiranía de la así llamada «realidad» en aras de un nuevo y vigoroso abrazo a los márgenes libres e ilimitados de la imaginación. No es de extrañar que las simpatías de Gilliam se inclinen hacia el personaje de Jacob «Jake» Grimm (Heath Ledger), quien al contrario que su hermano, el más pragmático Wilhelm «Will» Grimm (Matt Damon), cree a pies juntillas en la magia y la fantasía, la que desprenden los relatos populares que va recopilando en ese diario que siempre lleva consigo, hasta el punto de acabar contagiando a su escéptico hermano (Fernández 2005).

I encara més:

But Gilliam, over the course of the film, rejects this identification in order to hold up the truth of story-telling against the truth of reason: after many twists, Wilhelm concedes to Jacob that magic beans can cure, and, as a symbol of fairytale itself, are the only medicine that matters. The dead children come back to life, their village is restored to harmony, now released from its curse (Warner 2005).

Pel que fa al paper dels actors que interpreten els personatges (recordem que Matt Damon és Will i Heath Ledger és Jake), resulta interessant veure quina és aquesta tria perquè també ens permet copsar la perspectiva del director. Quan li pregunten a Matt Damon per què escull el paper de Will, ell contesta:

Because I was doing Stuck on You, ${ }^{17}$ this movie that's going to come out from the Farrelly Brothers. And Greg Kinnear was playing the «Will» role and I was playing the «Jake» role, basically. Terry said that in real life Heath's more like Will and I'm more like Jake. Getting to know Heath more, I don't know that's true, in the sense that Heath isn't that cynical and there are a lot of qualities that Heath has that Will doesn't have. But what I think he meant, and what it felt like to me that he meant at the time, is that Heath is this dashing leading man and I'm more of an internal person, and Jake is kind of in his world of books, and so it would have been a much easier fit, I think, to do it that way. It would have been less distance to travel for either of us, which was kind of boring (McCabe 2006: 242-243).

Aquesta contraposició de caràcters (també en el cas dels actors) dóna vida a la parella protagonista i acosta als espectadors aquesta versió dels germans Grimm convertits en personatges de ficció i protagonistes de les seves rondalles.

I7. Stuck on you (Pegado a ti, 2003), de Bobby i Peter Farrelly, protagonitzada per Matt Damon (Bob Tenor) i Greg Kinnear (Walt Tenor), que interpreten dos germans siamesos. 


\section{El salt a la televisió: Grimm (2011-2012)}

El 28 d'octubre de 2OII, la cadena nord-americana NBC estrena l'emissió d'una nova sèrie titulada Grimm, una proposta dramàtica que barreja fantasia, misteri i crim prenent com a base les rondalles dels germans Grimm. ${ }^{18}$ L'emissió d'aquesta nova sèrie cal contextualitzar-la en la que s'ha anomenat «era del drama» (definida per Longworth) (Tous 20Io), en què trobem a la petita pantalla noves propostes de ficció que disposen d'un ampli suport del públic receptor i que poden suposar noves aportacions respecte a la crisi d'idees que viuen les produccions de Hollywood de fa anys. ${ }^{19}$ Sèries de gèneres diversos com The west wing (NBC, I999-2006), Lost (ABC, 2OO4-2OIO), How I met your mother (CBS, 2005-) o Game of thrones (HBO, 2OII-), per citar-ne només quatre, de diferents períodes i cadenes, són un bon exemple d'aquesta nova època daurada de la televisió, que no es manté al marge d'aquesta cerca de noves idees. Així, si el darrer exemple citat (Game of thrones) és una adaptació televisiva d'una saga de

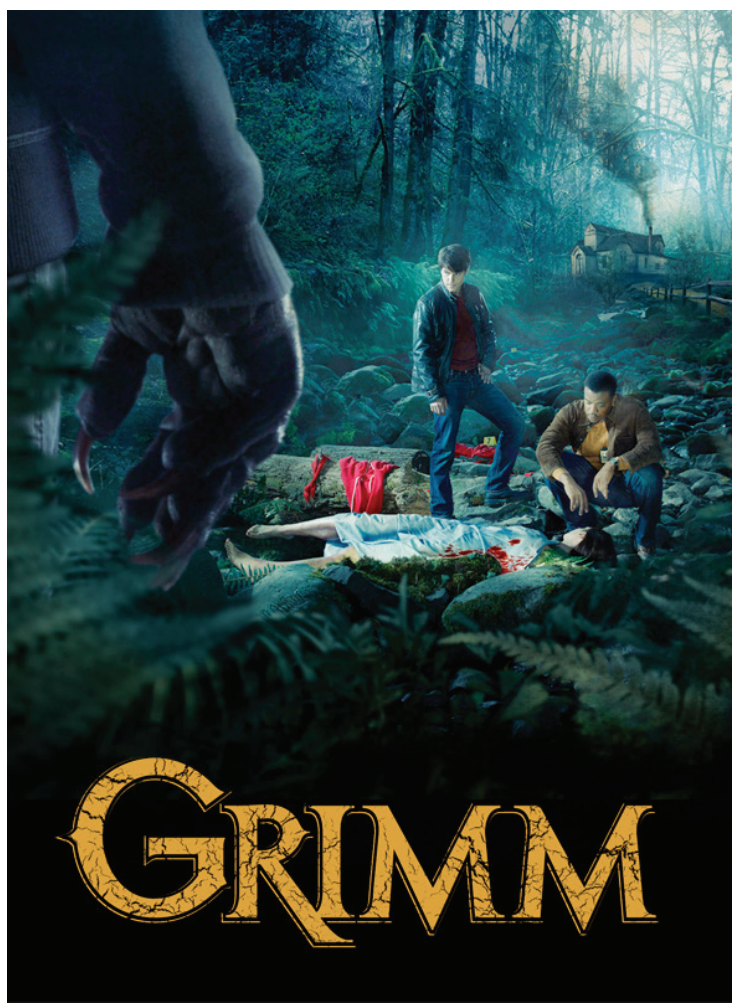

I8. La sèrie l'ha estrenada a Espanya en obert la cadena Cuatro la mitjanit de l'II de juliol de 2012.

I9. Un clar exemple d'aquesta crisi d'idees la trobem en la mirada cap a altres arts, amb la proliferació d'adaptacions literàries i, en els darrers anys, d'adaptacions de còmics per a la pantalla gran, amb resultats dispars. 
novel-les publicades prèviament, ${ }^{20}$ la sèrie Grimm troba en les rondalles el material argumental per elaborar els diferents episodis de la sèrie, com veurem. La cadena NBC no és pas l'única que busca en aquestes rondalles inspiració per a noves creacions. Pocs dies abans de l'estrena de Grimm, ${ }^{21}$ la també nord-americana $\mathrm{ABC}$ emet el primer episodi d'una nova sèrie titulada Once upon a time (Hi havia una vegada), que també s'inspira en les rondalles. En aquest cas, no és tan evident la relació concreta amb les rondalles dels Grimm, ja que la sèrie presenta més similituds, pel que fa a argument i desenvolupament de la història, amb el reeixit còmic Fables, creat per Bill Willingham dins del segell Vertigo de DC Comics (2002-), ${ }^{22}$ que ens presenta versions actuals dels personatges més coneguts de les rondalles i que beu d'altres fonts (a banda dels Grimm). En tot cas, tant Grimm com Once upon a time acosten als espectadors de la petita pantalla les històries que, fins no fa pas tants anys (encara que no ho sembli), s'explicaven a la vora del foc.

La primera temporada de Grimm està formada per 22 episodis, emesos del 28 d'octubre de 20 I al i8 de maig de 20I2, amb cert èxit si tenim en compte l'anunci, el I6 de març, de la renovació per a una segona temporada, que s'ha previst que es comenci a emetre el I3 d'agost de 2012. Creada per Stephen Carpenter, David Greenwalt i Jim Kouf, la sèrie està protagonitzada pel detectiu d'homicidis de Portland Nick Burkhardt (interpretat per David Giuntoli), a qui li canvia la vida quan descobreix que és un «Grimm», això és, el descendent d'una línia d'elit de caçadors encarregats de mantenir l'equilibri al món entre els éssers humans i les criatures sobrenaturals (procedents de rondalles i mites) que l'habiten. Com a tal, té la capacitat de distingir aquestes criatures (conegudes, genèricament, com a «Wesen») ${ }^{23}$ d'entre la resta d'humans i de veure'n la vertadera forma. El protagonista viurà així una doble vida, com a detectiu i com a Grimm, acompanyat en el primer cas pel seu company Hank Griffin (in-

20. Fins al moment, s'han publicat cinc llibres (d'un total de set) de la saga escrita per George R. R. Martin, coneguda com «Song of ice and fire» («Cançó de gel i foc»): Game of thrones (1996), Clash of kings (1999), Storm of swords (2000), Feast for crows (2005), Dance with dragons (2OII), tots traduïts al castellà per Gigamesh i, recentment, al català per Alfaguara. La sèrie de televisió, que pren el títol del primer llibre (Game of thrones) ha emès dues temporades (2OII-2OI2), que han adaptat els dos primers llibres i es troba en fase de rodatge la tercera, l'estrena de la qual està prevista per al 3I de març de 2013.

2I. Concretament, el 23 d'octubre de 201 II.

22. Al mercat espanyol l'editorial ECC (El Catálogo del Cómic) és la que en té actualment els drets i publica de manera regular els recopilatoris americans. Els volums anteriors havien estat publicats per Norma Editorial, primer, i per Planeta de Agostini, després.

23. El mot alemany «Wesen» pot traduir-se com «ésser» i a la sèrie s'utilitza com a genèric per designar aquestes criatures mitològiques que viuen entre els éssers humans adoptant forma humana, sent visibles per als Grimm en la seva forma de criatura. Dins d'aquests «Wesen» es distingeixen diferents races o espècies (unes vint-i-cinc de conegudes en aquesta primera temporada) que representen els personatges fantàstics que trobem a les rondalles (el llop, els tres porquets, la guineu, etc.) tant en la forma (el seu aspecte) com en el fons (el seu caràcter i comportament). 
terpretat per Russell Hornsby) i en el segon per Eddie Monroe (interpretat per Silas Weir Mitchell), un «Wesen» reformat (concretament, es tracta d'un «Blutbad», l'equivalent al llop de les rondalles). Al mateix temps, es desvetllaran pistes sobre el seu passat i l'herència rebuda com a Grimm. Tot plegat afectarà la relació amb la seva xicota, Juliette Silverton (interpretada per Bitsie Tulloch), que en desconeix la naturalesa.

La cerca de pistes que li expliquin el passat al protagonista és un dels eixos d'aquesta primera temporada, però més enllà de veure com aquesta línia familiar es remunta fins als germans Grimm, el que m'interessa analitzar de la sèrie són les versions actuals de les rondalles que es troben a cada episodi, com veurem tot seguit.

\subsection{Contes d'infants i de la llar en el segle XXI}

Els episodis d'aquesta primera temporada de la sèrie tenen una estructura regular, que es repeteix gairebé sempre, sobretot a partir de la descoberta del protagonista de la seva condició de Grimm (ja al primer episodi). Així, generalitzant, trobem un cas policial inicial, de circumstàncies anormals, que el Nick investiga com a detectiu, primer, i com a Grimm, després. Amb l'ajut de Monroe i del material que troba dins la caravana de la seva tia Marie Kessle, la seva antecessora com a Grimm (interpretada per Kate Burton), identifica l'espècie a la qual pertany el responsable d'aquell cas, per buscar tot seguit com aturar-lo. Finalment, combinant les seves dues facetes (de detectiu i de Grimm), i amb l'ajut dels companys i de les seves habilitats, el protagonista resol el cas. Aquesta resolució pot anar acompanyada d'una nova pista (o enigma) en relació amb el seu passat i el llinatge dels Grimm.

Sota aquesta estructura bàsica (repeteixo que he generalitzat), cada episodi presenta una versió actualitzada d'una rondalla. La identificació es facilita a l'inici de l'episodi, amb la inclusió d'una cita que recull un fragment del relat que es versiona. El grau d'adaptació és dispar, però acostuma a anar més enllà d'un simple detall, com hem vist als motius presents en determinades escenes de The brothers Grimm. Dels 22 episodis de la primera temporada, I2 són adaptacions de rondalles procedents del recull dels germans Grimm, 3 són adaptacions parcials i les 7 restants adapten relats procedents d'altres fonts que no són els Grimm. Per veure en conjunt el grau d'adaptació dels episodis d'aquesta primera temporada, he elaborat un quadre (figura I) que inclou la informació següent:

- Número de l'episodi i títol (original).

- Data d'emissió de l'episodi a la cadena NBC.

- Cita inicial que apareix en cada episodi. ${ }^{24}$

24. Resulta molt útil, en aquest sentit, la «Grimm guide» que la cadena NBC té al seu web dedicat a la sèrie. 
El llegat dels germans Grimm en el segle XxI: del paper a la pantalla

- Font en què es basa l'episodi.

- Tipus rondallístic ATU (Uther 2004).

- Número i títol de la rondalla al recull dels Grimm (KHM).

A partir de les dades recollides en aquest quadre exploraré a continuació alguns detalls de cada episodi, seguint l'esquema següent: títol de l'episodi i número, títol i tipus ATU (Uther 2004) si en té, font en què es basa l'episodi (número i títol de la versió en el cas de les rondalles dels germans Grimm als KHM), seguida de la traducció catalana.

Els 7 episodis que no tenen cap relació amb les rondalles dels Grimm estan inspirats en altres relats que també provenen de la rondallística, o bé pertanyen a obres literàries conegudes i que tracten temes fàcilment recognoscibles pels espectadors i que tenen moltes similituds i punts en comú amb els contes.

(1) «Bears will be bears» (episodi 2), «Goldilocks and the three bears»

(«Rínxols d'or i els tres óssos»), de Robert Southey.

Aquest episodi es basa en «Goldilocks and the three bears» («Rínxols d'or i els tres óssos»), de Robert Southey, una rondalla prou coneguda i adaptada anteriorment a la televisió, al teatre i al cinema, protagonitzada per tres óssos. A la sèrie, Gilda Darner (interpretada per Amy Gumenick) adopta el paper de Goldilocks i els óssos estan representats per la raça de «Jägerbars», que protagonitzen un cerimonial d'iniciació que no trobem a la rondalla.

(2) «The three bad wolves» (episodi 6), «Blowing the house in», ATU I24, «The three little pigs» («Els tres porquets»).

L'episodi adapta la coneguda rondalla dels tres porquets tot capgirant la situació, amb els porcs («Bauerschwein») que assassinen llops («Blutbad») com a venjança. L'originalitat de l'episodi es troba en aquest canvi de rol dels personatges.

(3) «Of mouse and man» (episodi 9), Of mice and men (Homes i ratolins), ${ }^{25}$ de John Steinbeck.

Aquest episodi es basa en la novel-la Of mice and men, de John Steinbeck, publicada el I937, i aprofita el fons, però també la forma de la novel·la (en la literalitat del títol) presentant l'enfrontament entre depredadors («Lausenschlange» o serps) i preses («Mauzhertz» o ratolins).

(4) «Tarantella» (episodi II), «The goblin spider» («L'aranya follet»).

L'episodi adapta una rondalla japonesa («The goblin spider») traduïda a l'anglès per Lafcadio Hearn i publicada per Hasegawa l'any I899 sobre una vídua negra (de la raça «Spinnetod» o aranya).

25. En la traducció de Manuel de Pedrolo dins la col-lecció A Tot Vent de l’any I964.

Estudis de Literatura Oral Popular, núm. I, 2012 
(5) «Last Grimm standing» (episodi I2), «Androcles and the lion», ATU I56, Noctes atticae (Nits àtiques), d'Aulus Gel·li.

Aquest episodi recupera un relat recollit per Aulus Gel-li a les Noctes atticae sobre Àndrocles i el lleó (concretament al llibre V.I4), ${ }^{26}$ que ha estat recollida també com a llegenda en altres indrets. ${ }^{27}$ En aquest cas, el Circ Màxim que rebia les feres i els condemnats es conserva com a arena on se celebren lluites il.legals entre espècies «Wesen» diferents.

(6) «The thing with feathers» (episodi I6), «The nightingale» («El rossinyol»), de Hans Christian Andersen.

L'episodi adapta la rondalla «The nightingale», publicada per Hans Christian Andersen el I843, tot presentant una nova criatura dins la sèrie ( «Seltenvogel»), un estrany ocell de gran valor per les pedres d'or que pot crear.

(7) «Leave it to the beavers» (episodi I9), «Wait for the fat goat», ATU I22E, «De tre bukkene Bruse» («Les tres cabres mascle Gruff»), de Peter Christen Asbjørnsen i Jørgen Moe.

El darrer d'aquests set episodis sense relació amb les rondalles dels germans Grimm es basa en una rondalla noruega, «De tre bukkene Bruse», recollida per Peter Christen Asbjørnsen i Jørgen Moe entre I84I i I844, que pertany al tipus ATU I22E. A l'episodi es reprodueix el xantatge que trobem a la rondalla entre el troll i les cabres que volen creuar el pont. Els «Hässlich» (trolls) creuen que tots els ponts són seus i exigeixen diners als constructors («Eisbiber»).

Hi ha 3 episodis que adapten de manera parcial rondalles dels germans Grimm. Es tracta de casos en què la font utilitzada pels guionistes no és la versió dels Grimm, sinó una altra, tot i que als KHM hi trobem una versió de la mateixa rondalla.

(1) «BeeWare» (episodi 3), Queen bee (L'abella reina).

L'episodi pren com a referència la pel-lícula Queen bee (I955), com mostra la cita inicial que recull unes paraules de la protagonista Carol Lee Philips (interpretada per Betsy Palmer), més que no pas la rondalla no 62 dels KHM dels Grimm, «Die Bienenkönigin» («La reina de les abelles»), que pertany al tipus ATU 554. Les abelles de la rondalla estan representades a l'episodi amb la raça de les «Mellifer».

26. Es pot llegir una traducció al català d'aquesta història dins l'antologia de les Nits àtiques d'Aulus Gel-li a cura d'Albert Andrade i Bàrbara Matas, publicada a La Magrana el 1997. Aquesta mateixa història ha estat adaptada literàriament per George Bernard Shaw i adaptada al cinema en dues ocasions: Androcles, de Louis Fevillade (I9I2), i Androcles and the Lion, de Chester Erskine (I952).

27. Aquesta mateixa història s'explica com a origen (entre d'altres) del nom de la platja del Miracle a Tarragona, com recullen alguns autors (Samper 20I0: 85). 
(2) «Lonelyhearts» (episodi 4), «Maiden-Killer (Bluebeard)», ATU 3I2, «La Barbe Bleue» («Barbablava»), de Charles Perrault.

Aquest episodi es basa en la versió de la coneguda rondalla «Barbablava», de Charles Perrault, tot i que els germans Grimm també en van publicar una versió («Blaubart») que trobem només en la primera edició dels KHM de I8I2, amb el no 62, i que pertany al tipus ATU 3I2. A «Lonelyhearts» veiem en acció un «Ziegevolk» (conegut també com a «Bluebeard») que utilitza les seves feromones per seduir les seves víctimes. Aquesta figura està basada parcialment en els sàtirs grecs i els faunes romans.

(3) «Game ogre» (episodi 8), «The brave tailor», ATU I640, «Jack the giant killer» («Jack el matagegants»).

El darrer episodi d'aquest grup es basa en la rondalla «Jack the giant killer», que guarda certes similituds amb la rondalla no 20 dels KHM dels germans Grimm, «Das tapfere Schneiderlein»(«El sastre valent»). En aquesta versió, en Monroe adopta el paper de matagegants (ajudat per un rifle especial que es troba a la caravana de la tia Marie) quan derrota l'amenaça que suposa un «Siegbarste» (l'equivalent a l'ogre).

Els I2 episodis que adapten rondalles dels germans Grimm ho fan amb diferents graus de fidelitat respecte a l'original.

(1) «Pilot» (episodi I), «Little Red Riding Hood», ATU 333, KHM n 26, «Rotkäppchen» («Caputxeta Vermella»).

L'episodi pilot serveix per introduir en escena la raça dels «Blutbaden», que representen la figura del llop que trobem en rondalles com la de la mateixa Caputxeta o la dels tres porquets. Aquestes criatures senten atracció pel color vermell, motiu que lliga la desaparició de personatges femenins que duen parts de la vestimenta d'aquest color (com ara una jaqueta de xandall) amb la rondalla de la «Caputxeta Vermella». Aquest episodi serveix per posar en contacte la parella protagonista formada per en Nick (un Grimm) i en Monroe (un «Blutbad»), que, un cop passat l'enfrontament inicial, formaran equip tot i pertànyer a races enfrontades. De fet, en Monroe cobrarà cada cop més protagonisme durant la temporada en aquest paper de conseller i company del protagonista.

(2) «Danse macabre» (episodi 5), «The rat-catcher», ATU 570*, DS n 245, «Der Rattenfänger von Hameln» («El caçador de rates d'Hamelin»). Aquest episodi versiona la llegenda d' «El caçador de rates d'Hamelin», recollida pels germans Grimm a les Deutsche Sagen, amb el no 245, «Der Rattenfänger von Hameln». ${ }^{28}$ Es tracta de l'únic cas en què es versiona un relat dels Grimm que no procedeix dels KHM. L'episodi actualitza el paper del flautista fent que el personatge que l'interpreta sigui un jove que

28. Davant l'absència d'una traducció completa de les Deutsche Sagen dels Grimm al català i a l'espanyol, una traducció a l'espanyol d'aquesta llegenda es pot llegir a l'antologia Leyendas alemanas, traduïda per Pedro Gálvez (2000: IO6-IO9) amb el títol «Los niños de Hameln». 
pateix assetjament escolar per part dels companys, així com el rebuig i la burla d'ells respecte al seu pare. El flautista és en aquest cas un violinista (Roddy Geiger, interpretat per Nick Thurston), ficat en la pell d'un famós discjòquei que amaga la seva identitat sota la màscara d'un gat i que es venja utilitzant el seu control sobre les rates, com el llegendari flautista.

(3) «Let your hair down» (episodi 7), «The maiden in the tower», ATU 3IO, KHM n I2, «Rapunzel» («Repunxó»).

La protagonista de l'episodi és una nena, Holly Clark (interpretada per Mary Jon Nelson), atrapada en aquest cas no en una torre com el personatge de la rondalla, sinó al bosc, on ha crescut sola. De fet, és presonera de la seva naturalesa, ja que no sap que és una «Blutbad» perquè s'ha criat tota sola al bosc, on viu en un refugi dalt d'un arbre (és la seva torre). La similitud amb la rondalla es completa amb la utilització que la protagonista fa dels seus llargs cabells, que usa com a arma defensiva.

(4) «Organ grinder» (episodi Io), «Hansel and Gretel», ATU 327A, KHM $\mathrm{n}^{\circ}$ I5 «Hänsel und Gretel» («Ton i Guida»).

Aquest episodi modernitza la rondalla de «Hansel and Gretel». Si en la rondalla original els dos germans són temptats per la caseta de xocolata on viu una bruixa que se'ls vol menjar, en aquest episodi la temptació ve donada en forma d'una promesa de feina estable per part d'un col-lectiu que segresta joves per robar-los els òrgans i traficar amb ells. Així, la parella de germans protagonistes d'aquest episodi, Hanson (interpretat per Daryl Sabara) i Gracie (interpretada per Hannah Marks), representen una versió actualitzada de Hansel i Gretel (o Ton i Guida). D'altra banda, el motiu del segrest per robar el òrgans i traficar amb ells lliga també amb un rumor o llegenda urbana que trobem també de manera recurrent actualment. ${ }^{29}$

(5) «Three coins in a Fuchsbau» (episodi I3), «Tasks for a thief», ATU I525A, KHM n I92, «Der Meisterdieb» («El lladre de lladres»).

Aquest episodi gira al voltant d'unes monedes (les «monedes de Zakynthos»), que, com a objecte màgic, aconsegueixen que el seu propietari pugui obtenir el que vulgui, a canvi, això sí, d'un preu. Aquesta qualitat de les monedes les acosten a la rondalla «Der Meisterdieb», (ATU I525A), protagonitzada per un lladre traçut que aconsegueix tot el que es proposa. A banda d'aquesta similitud, aquest episodi no manté més relació amb la rondalla i se centra, sobretot, en el poder d'aquestes monedes que han passat per mans dels grans i poderosos personatges històrics (des d'emperadors romans com August, Calígula o Neró fins a Hitler, entre d'altres).

29. Es tracta del rumor 2. «El ronyó extirpat», dins del recull de Josep M. Pujol i el Grup de Recerca Folklòrica d'Osona dedicat a l'estudi d'aquests relats (GRFO/Pujol 2002: 79-87). 
(6) «Plumed serpent» (episodi I4), «The twins or blood-brothers», ATU 303, KHM no 60, «Die zwei Brüder» («Els dos germans»).

L'episodi es relaciona amb la rondalla «Die zwei Brüder», que pertany al tipus ATU 303. De fet, l'episodi recrea el clàssic enfrontament entre l'heroi i el drac per salvar la princesa, més que entrar en els detalls que caracteritzen aquest tipus. Així, en Nick adopta el paper del cavaller i s'enfronta al drac, en aquest cas un «Dämonfeuer» que busca morir honorablement en combat. Pel que fa al conjunt global de la sèrie, aquest és el primer episodi en què apareixen els dubtes en la relació entre el protagonista, Nick, i la seva xicota, Juliette (desconeixedora de la veritable naturalesa del seu xicot com a Grimm), que es veu involucrada en l'acció.

(7) «Island of dreams» (episodi I5) i «Love sick» (episodi I7), «The magic bird-heart», ATU 567, KHM n I22, «Der Krautesel» («L'amanida»).

Aquests dos episodis es poden analitzar conjuntament perquè tots dos es basen en la mateixa rondalla, coneguda també com «Donkey cabbages or the donkey cabbage», que pertany al tipus ATU 567. Tots dos episodis obvien les transformacions en ruc que apareixen en la rondalla i se centren en detalls argumentals concrets de la versió dels Grimm. Així, en Hank, el company d'en Nick, adopta el paper del caçador que s'enamora de la filla d'una bruixa (la filla és Adalind Schadem, interpretada per Claire Coffee), que busca l'aprovació de la seva mare. És per això que l'enverina utilitzant una poció d'amor per poder arribar fins a en Nick, que, com a Grimm, és el seu enemic.

(8) «Cat and mouse» (episodi I8), «Goldener», ATU 3I4, KHM n I36, «Der Eisenhans» («El Janferrís»).

L'episodi s'endinsa en els «Wesen» i la seva estructura social i política, amb l'enfrontament entre "Verrat», una societat suprema formada per forces de l'autoritat que busquen l'equilibri entre les diferents races, i «Laufer» que, com a força rebel, s'oposen a aquesta autoritat. L'element que uneix aquest episodi amb la rondalla no 136 , «Der Eisenhans», dels KHM dels Grimm és la presència dels «Hundjäger», una raça de gossos que encarnen la força de la societat «Verrat» i en són el braç executor. Aquests gossos tenen similituds amb els que apareixen a la rondalla dels Grimm. Més enllà d'aquest detall, és la lectura política el que centra aquest episodi, amb el protagonisme d'Ian Harmon (interpretat per Neil Hopkins) com a líder de la resistència «Laufer».

(9) «Happily ever aftermath» (episodi 20), «Cinderella», ATU 5IOA, KHM no 2I, «Aschenputtel» («La Cendrosa»).

L'episodi reprèn, com el títol indica, la història de «La Cendrosa» (ATU 5IOA), després del seu matrimoni amb el príncep. Lluny de «ser feliços i menjar anissos», en aquesta versió moderna, ell, Arthur Jarvis (interpretat per David Clayton Rogers), perd la seva fortuna en una mala inversió, fet que no li agrada a ella, Lucinda Jarvis (interpretada per Amanda 
Schull), acostumada a un alt nivell de vida. La trama deriva cap al drama criminal, amb l'assassinat de la madrastra i la complicada relació entre les germanastres i la protagonista per l'herència deixada per la madrastra. En aquest episodi apareix la raça dels «Murciélago», que, a tall anecdòtic, té l'origen, com indica la forma del seu nom en espanyol, a Espanya.

(10) «Big Feet» (episodi 2I), «Hans my hedgehog», ATU 44I, KHM n Io8, «Hans mein Igel» («Hans, el meu eriçó»).

L'episodi adapta la rondalla a partir de l'adopció del personatge protagonista que apareix al no Io8 dels KHM, «Hans mein Igel». Seguint la dualitat del protagonista de la rondalla (meitat home, meitat bèstia), a l'episodi trobem la raça dels «Wildermann», que també recullen la tradició dels anomenats Bigfoot, com es reflecteix al títol. A diferència del protagonista, però, Larrie Mackenzie, amic d'en Monroe (interpretat per Kenneth Mitchell), no aconsegueix alliberar-se de la seva part bestial. El desenvolupament de la història i la presència del doctor Konstantin Brinkerhoff (interpretat per Roger Bart) acosten també aquest episodi a la coneguda història del Doctor Jekyll i Mr. Hyde, de Robert Louis Stevenson.

(11) «Woman in black» (episodi 22), «Sleeping beauty», ATU 4IO, KHM nº 50, «Dornröschen» («Englantina»).

L'episodi clou la primera temporada de la sèrie, desvetllant part dels misteris que s'han desgranat durant els anteriors episodis i oferint-ne de nous, com acostuma a passar en els episodis de final de temporada. En relació amb les rondalles, aquest final adapta un dels motius que trobem a la rondalla $n^{\circ} 50$ dels KHM, «Dornröschen», i al tipus ATU 4IO, que és el motiu Di364.I7, «Spindle causes magic sleep». En aquest cas, qui adopta el paper de la princesa com a víctima és la Juliette, la xicota d'en Nick (veterinària de professió), que cau adormida per l'encanteri que la bruixa Adalind fica a les ungles del seu gat, que l'esgarrapa. Així, la maledicció no es transmet a través d'una agulla, sinó d'aquest animal.

Aquest episodi final tanca una primera temporada que ha aportat, pel que fa a la relació amb les rondalles dels germans Grimm, adaptacions de caire divers, com hem vist, des de recreacions més literals fins a episodis on la rondalla dels Grimm només servia d'element ornamental dins la trama i quedava en un pla més discret. En tot cas, cal destacar el treball d'adaptació dut a terme pel que fa a les diferents espècies de «Wesen» que recullen la caracterització de les criatures que trobem a les rondalles, així com els canvis de rol dels personatges. 
El llegat dels germans Grimm en el segle XxI: del paper a la pantalla

\section{Conclusions: rondalles a la vora de la pantalla i creadors com a personatges de ficció}

L'anàlisi de les rondalles que s'han extret de la pel-lícula The brothers Grimm i dels episodis de la primera temporada de la sèrie Grimm demostra com és possible reinventar aquestes històries transmeses oralment al llarg de la història i que han perviscut en paper en reculls com els dels germans Grimm. El grau de fidelitat pot ser més o menys elevat, però en tots els casos exposats s'hi ha vist aquesta intencionalitat de dotar d'un nou aspecte una història coneguda, mantenint la fidelitat per fer-la més fàcilment recognoscible (i buscar la complicitat amb l'espectador), com a The brothers Grimm, o bé adoptant una estètica (forma) però també una lectura (fons) més acostada als nostres dies, com a la sèrie Grimm. Això fa que l'escenari on s'explicaven les rondalles (la vora del foc) es substitueixi per la vora de la pantalla, sigui al cinema o a casa.

D'altra banda, noves propostes com la de la sèrie Grimm, que converteix l'herència dels dos germans en tota una nissaga de caçadors de criatures sobrenaturals, o la recreació de la vida dels mateixos Jacob i Wilhelm (amb totes les llicències que es vulguin i més) converteixen els autors dels Kinder- und Hausmärchen en personatges de ficció que protagonitzen precisament les rondalles que ells van recollir. Tot plegat fa que avui, en el segle xxi de les tecnologies de la informació i la comunicació, de les pantalles, del món audiovisual i de tantes coses que ens allunyen del segle XIX que va acollir el treball dels dos germans nascuts a Hanau, el seu llegat sigui ben viu. I per molts anys.

\section{Bibliografia}

Alarcón Celaya, Javier (20IO): «Los hermanos Grimm». Dins Juan Agustín Mancebo RocA (ed.). Terry Gilliam. El desafio de la imaginación. Madrid: T\&B Editores, p. I3I-I38.

AARne, Antti; Stith Thompson [AaTh] (I96I): The Types of the Folktale. A Classification and Bibliography. Folklore Fellows' Communications I84. Helsinki: Suomalainen Tiedeakatemia.

CAHILL, Susan (20IO): «Through the looking glass: fairy-tale cinema and the spectacle of femininity in Stardust and The brothers Grimm». Marvels \& Tales vol. 24, núm. I (2010): 57-67.

DíAz VILlaRíAs, Mercedes; Javier GARCíA RodRíguez (20IO): «La contradicción como deformación del orden». Dins Juan Agustín MANCEBO RocA (ed.). Terry Gilliam. El desafio de la imaginación. Madrid: T\&B Editores, p. I3-25.

Estudis de Literatura Oral Popular, núm. I, 2012 
FernÁndeZ VALENTí, Tomàs (2005): «El secreto de los hermanos Grimm: vidas de cuento». Dirigido por... Revista de Cine núm. 349 (octubre 2005): I2.

GEL·LI, Aulus (1997): Nits àtiques. Introducció, traducció, selecció i notes d'Albert Andrade i Bàrbara Matas. Barcelona: Edicions de la Magrana.

GRIMM, Jacobo Luis Carlos (I958): Cuentos de Grimm. Traducció de Montserrat Canal Rifa i il-lustracions de Lluís Casamitjana Colominas. Barcelona: Editorial Bruguera.

GRIMM, Jakob; Wilhelm GRIMM (2000): Leyendas alemanas. Traducció de Pedro Gálvez. Barcelona: Ediciones Obelisco.

Grimm guide - NBC < http://www.nbc.com/grimm/grimm-guide> [data de consulta: juliol 20I2].

GRUP DE RECERCA FolKòriCA D'Osona [GRFO]; Josep M. PUjOL (coord.) (2002): «Benvingut/da al club de la sida» i altres rumors d'actualitat. Centre de Promoció de la Cultura Popular i Tradicional Catalana. Barcelona: Departament de Cultura.

LOCHNER, Jim (2OIO): «The wonderful world of the brothers Grimm». FSMCD [Film Score Monthly] vol. I3, núm. 4 (2OIO): I-IO.

MCCABE, Bob (2006): Dreams and nightmares: Terry Gilliam, The brothers Grimm \& other cautionary tales of Hollywood. Nova York: Harper Collins.

Romero Peralta, Eduardo (I965): El maravilloso mundo de los hermanos Grimm. Il-lustracions de Marcelo Guillamón Pardo. Barcelona: Editorial Bruguera.

SAMPER Prunera, Emili (2OIO): «La petjada del rei En Jaume per terres tarragonines». Dins Carme ORIOL; Emili SAMPER (eds.): El rei Jaume I en l'imaginari popular i en la literatura. Tarragona / Palma: Publicacions URV / Edicions UIB, p. 73-99.

- (2012): "Carles Riba i les traduccions de les rondalles dels germans Grimm». Dins Actes del Setzè Col-loqui Internacional de Llengua i Literatura Catalanes. Salamanca, 20I2. Barcelona: Publicacions de l'Abadia de Montserrat [en premsa].

SPINES, Christine (2005): «El bosque encantado de Terry Gilliam. El secreto de los hermanos Grimm». Fotogramas \& DVD: La primera revista de cine núm. 1943 (setembre 2005): 92-95.

STEINBeCK, John (I964): Homes i ratolins. Traducció de Manuel de Pedrolo. Perpinyà: Proa.

THOMPSON, Stith (I955-I958): Motif-index of folk-literature: a classification of narrative elements in folktales, ballads, myths, fables, medieval romances, exempla, fabliaux, jest-books, and local legends. 6 vols. Bloomington: Indiana University Press. 
El llegat dels germans Grimm en el segle XxI: del paper a la pantalla

Tous, Anna (2010): La era del drama en televisión: Perdidos, CSI: Las Vegas, El ala oeste de la Casa Blanca, Mujeres desesperadas y House. Barcelona: Editorial UOC.

UTHER, Hans-Jörg [ATU] (2004): The Types of International Folktales. A Classification and Bibliography Based on the System of Antti Aarne and Stith Thompson. 3 vols. Folklore Fellows Communications 284-286. Helsinki: Suomalainen Tiedeakatemia.

WARNER, Marina (2005): «Dark Arts». The Guardian (I4 d'octubre de 2005): 6.

ZIPES, Jack (2OII): The enchanted screen: The unknown history of fairy-tales films. Nova York: Routledge. 


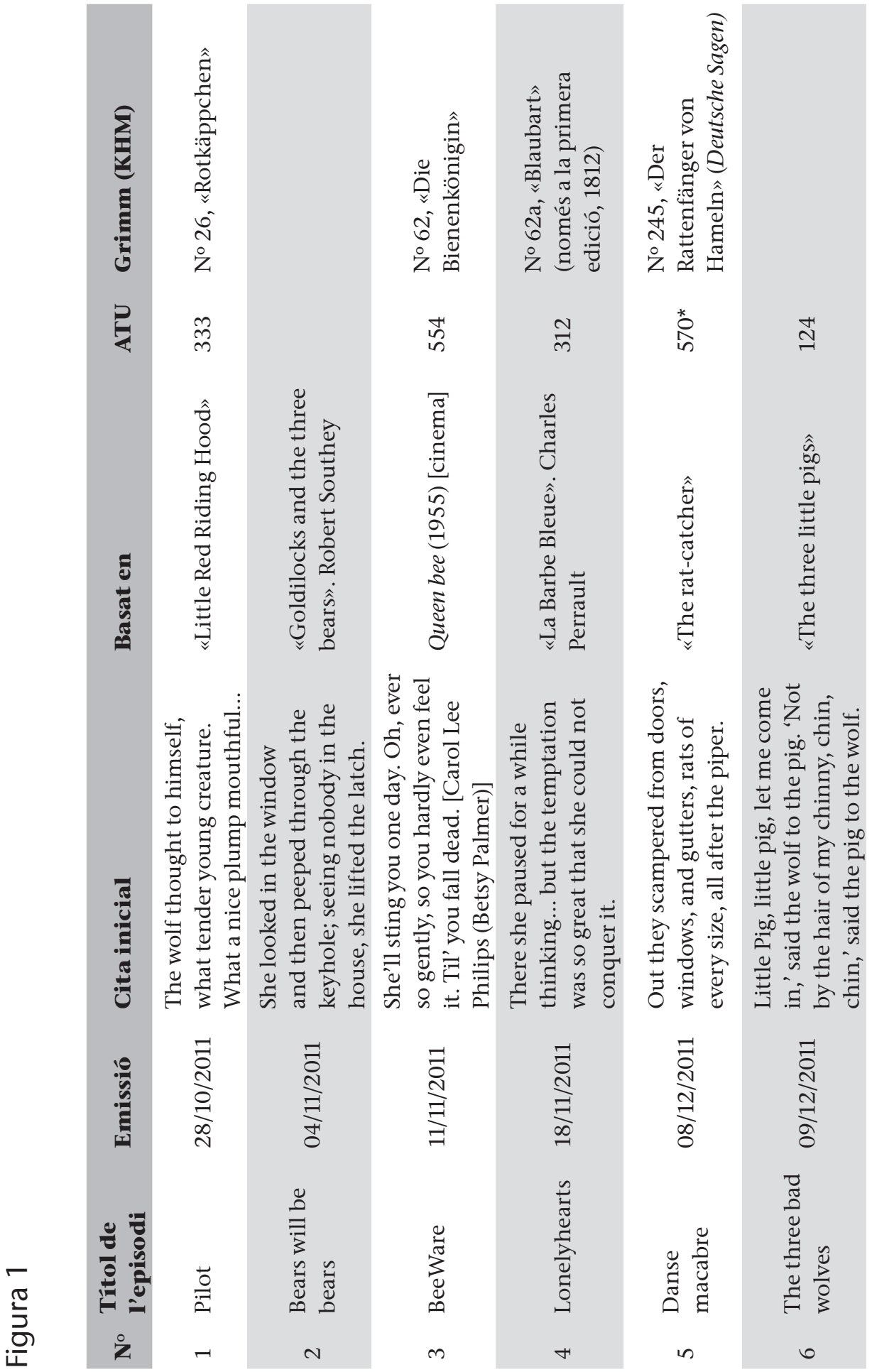


El llegat dels germans Grimm en el segle XXI: del paper a la pantalla

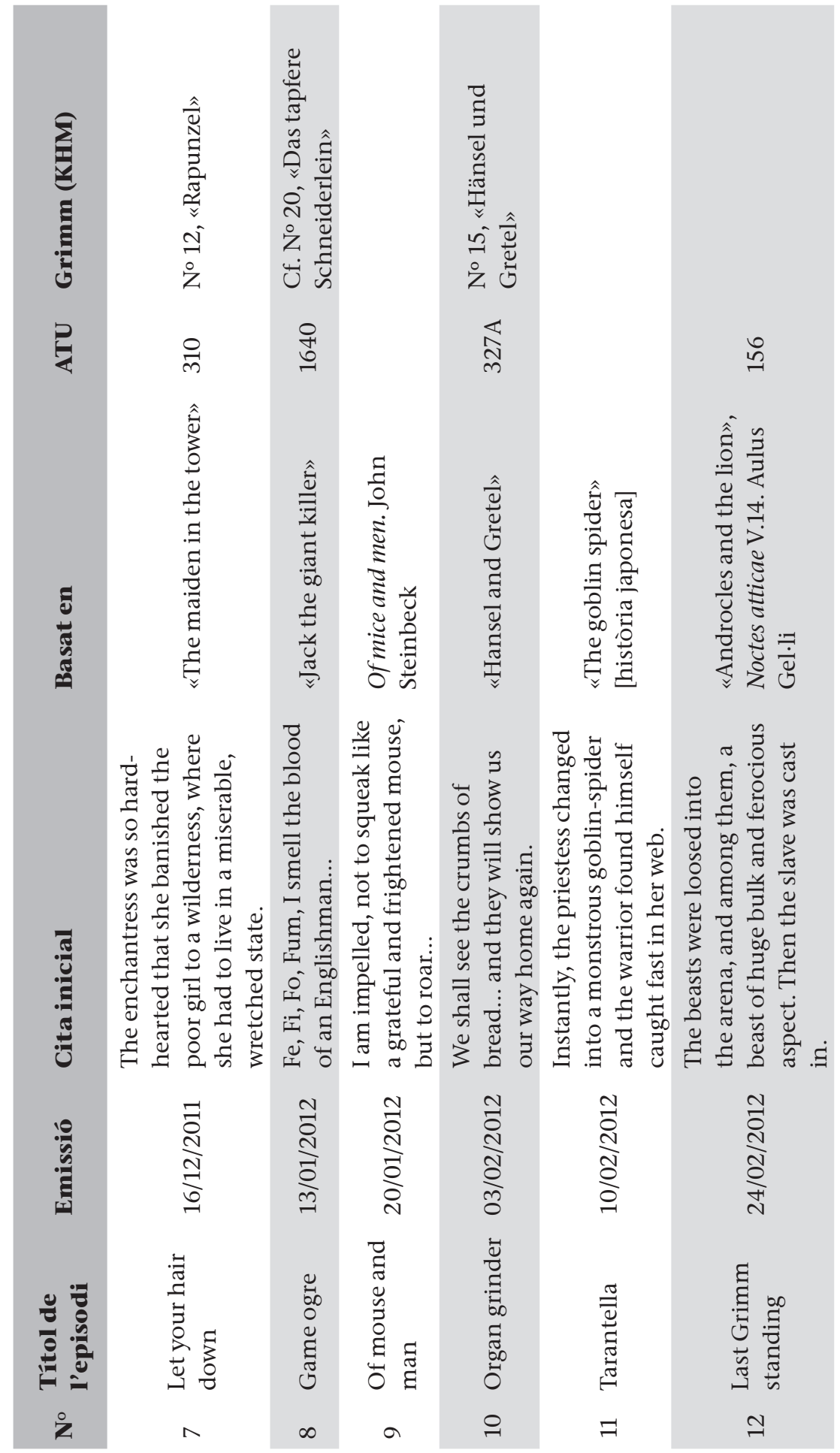




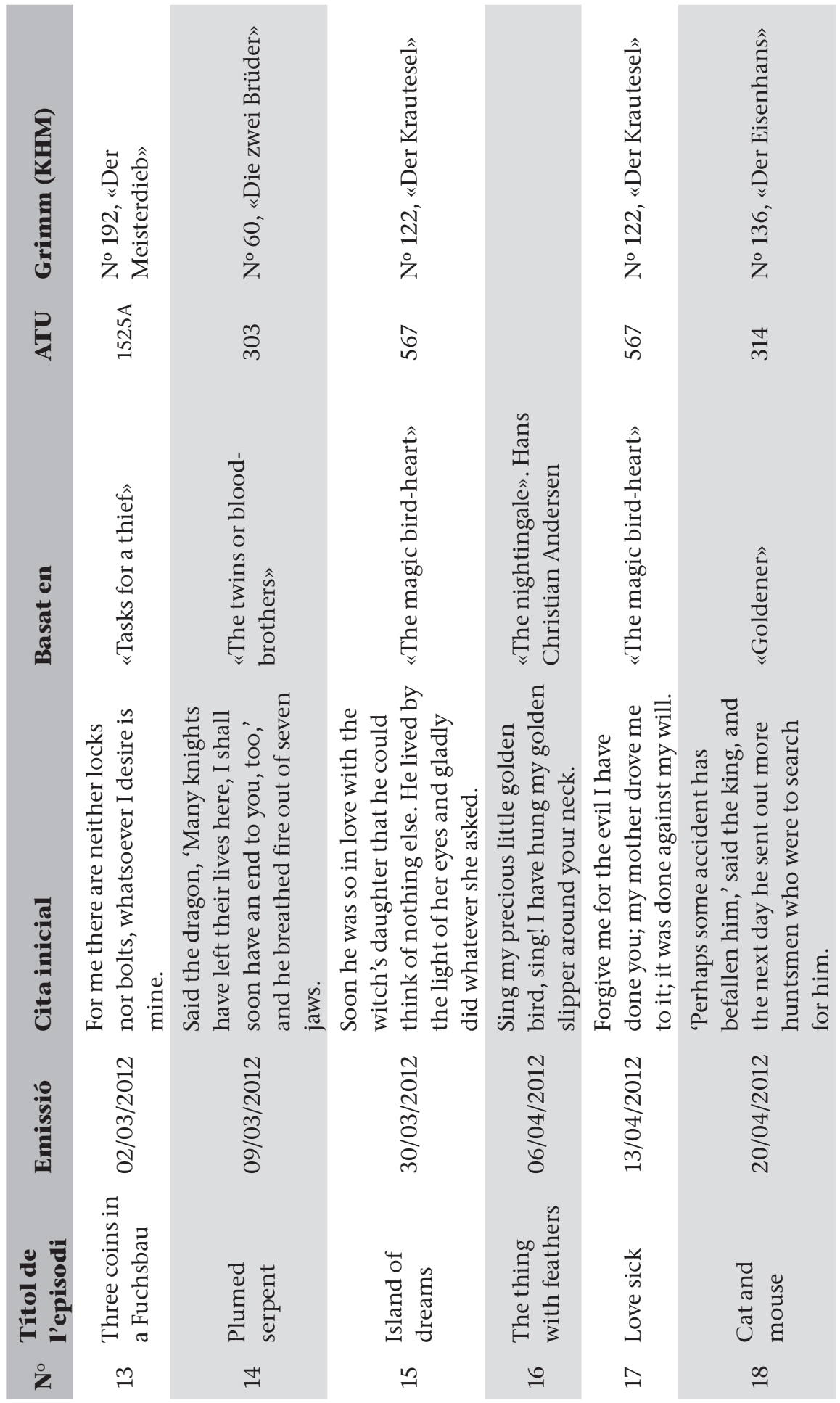


El llegat dels germans Grimm en el segle XxI: del paper a la pantalla

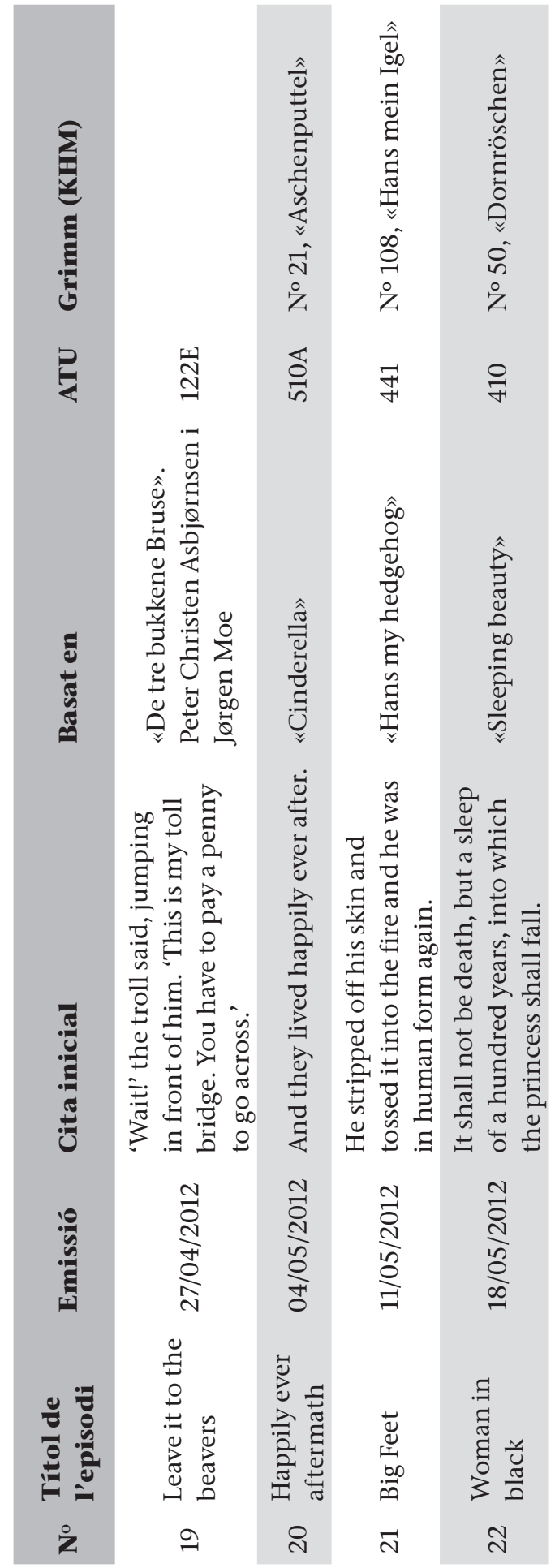

